\title{
INFLUENCE OF DIFFERENT LOADS ON THE PROPERTIES OF LIGHTWEIGHT COMPOSITE
}

\author{
Modestas Kligys $^{1}$, Marijonas Sinica ${ }^{2}$, Georgijus Sezemanas ${ }^{3}$, Kęstutis Miškinis ${ }^{4}$, Saulius Vaitkus ${ }^{5}$ \\ 1, 2, 3, 5 Vilnius Gediminas Technical University, Scientific Institute of Thermal Insulation, \\ Linkmenu g. 28, LT-08217 Vilnius, Lithuania \\ ${ }^{4}$ Kaunas University of Technology, Institute of Architecture and Construction, \\ Tunelio g. 60, LT-44405 Kaunas, Lithuania \\ E-mails: ${ }^{1}$ modestas.kligys@vgtu.lt (correspondingauthor); ${ }^{2}$ marijonas.sinica@vgtu.lt; \\ ${ }^{3}$ georgijus.sezemanas@vgtu.lt; ${ }^{4}$ kestutis.miskinis@ktu.lt; ${ }^{5}$ saulius.vaitkus@termo.vgtu.lt
}

Received 13 Feb. 2012; accepted 22 Mar. 2012

\begin{abstract}
The paper describes the study on the operational properties of lightweight composite with density of $150-$ $350 \mathrm{~kg} / \mathrm{m}^{3}$. It was established that these properties depend on the ratio of porous cement matrix and inclusions of crushed expanded polystyrene packing tare waste per unit volume of the lightweight composite. Studies have demonstrated that when the density of lightweight composite varies in the above mentioned limits, the compressibility amounts to 2.4$0.8 \mathrm{~mm}$, point load $-0.38-3.39 \mathrm{kN}$, dynamic stiffness $-35-135 \mathrm{MN} / \mathrm{m}^{3}$, and reduction in normalised impact sound pressure level - 26-17 dB. The dependences between the established properties and the density of lightweight composite are showed in the equations of regression. Possible versions for the use of lightweight composite in different constructions of floors and roofs are also provided.
\end{abstract}

Keywords: expanded polystyrene waste, compressibility, point load, dynamic stiffness, normalised impact sound pressure level.

\section{Introduction}

Plastics play an important role in our lives. They have been used in housing, packing, preservation and distribution of goods, many automotive, industrial and healthcare applications (Siddique et al. 2008). The rapid growth in the use of plastics leads in increased total garbage volume in dumps, causing serious environmental problems (Vasudevan et al. 2012).

It is possible to reduce the amount of plastic waste in dumps by using it as a raw material in the composites for the applications in civil engineering (Leu et al. 2012; Ahmed et al. 2011; Binici et al. 2012; Mohandesi et al. 2011). Utilisation of plastic waste saves manufacturing costs, $\mathrm{CO}_{2}$ emissions and natural raw materials (Poletto et al. 2011).

Expanded polystyrene (EPS) is a type of plastic, known for being hygienic and lightweight, highly able to absorb shocks, inexpensive, dimensionally stable and easy to produce (Shin 2006; GHK 2010; Schmidt et al. 2011). All these qualities make them irreplaceable for production of packing tare. Vast amounts of EPS packing tare are used for electronic devices, apparatus and their parts to ensure their safe transportation from manufacturer to customer.

Spherical EPS inclusions are also widely used to produce lightweight cement-based composites (Madandoust et al. 2011; Xu et al. 2012; Bouvard et al. 2007;
Guan et al. 2007). These composites have lower density, better thermal insulation and energy absorption.

In natural conditions, EPS waste does not disintegrate for very long periods of time, and its pressing is difficult because of reversible deformation (Kligys 2009). Some authors (Bhutta et al. 2011; Poletto et al. 2011; Schmidt et al. 2011; Gaggino 2006) have proposed innovative technologies for recycling of EPS waste by introducing them into the manufacturing process of different composites.

Quite recently the utilisation of EPS packing tare waste was a serious problem in Lithuania as it was simply dumped. Only as late as in 2006, the private company Virginijus and Co., Plungè, Lithuania developed a technology for the Eureka project E! 3446-Sandplast. Now, this company crushes EPS packing tare waste to required dimensions and uses it as an inclusion for the production of lightweight composite, offered by the VGTU Scientific Institute of Thermal Insulation. In this lightweight composite - with a density from 150 to $350 \mathrm{~kg} / \mathrm{m}^{3}-$ EPS inclusions are joined by a porous cement matrix.

The earlier researches (Sinica et al. 2008; Kligys et al. 2008) showed that the limit compressive strength $\sigma_{c}$ of lightweight composite makes $0.09-0.42 \mathrm{MPa}$, the limit flexural strength $\sigma_{b}$ is $0.09-0.39 \mathrm{MPa}$, the thermal conductivity coefficient $\lambda_{10^{\circ} \mathrm{C}}$ is $0.0489-0.0963 \mathrm{~W} / \mathrm{m} \cdot \mathrm{K}$, the specific water vapour resistance $\mu$ is $6.0-14.8$. Accord- 
ing to the standard LST EN 13501-1:2007, by class of combustibility, the lightweight composite may be allocated to class B-sl, d0.

Nevertheless, these properties are not enough to possibly extend the field of application of this lightweight composite, e.g. for floating floor or roof insulating constructions, where during the process of exploitation, different loads appear. Therefore, it is necessary to carry out the additional research of lightweight composite to determine such properties, as compressibility, ability to stand static and dynamic loads, as well as normalised impact sound pressure level.

Presently, in constructions of floating floor and flat roofs, lightweight materials, e.g. mineral wool and expanded polystyrene slabs are widely used. The operational properties of such materials is well investigated; therefore, it is of no difficulty to select any special material for different constructions (Buska et al. 2008; Dikavičius, Miškinis 2009; Miškinis 2010; Kim et al. 2009). However, the analysis of references showed that no sufficient data are available on abovementioned properties of lightweight composite. The purpose of this study is to investigate these properties.

\section{Materials and methods}

\subsection{Materials and preparation of samples}

Lightweight composite was produced using Portland cement of mark CEM I $42.5 \mathrm{R}$ conforming to requirements of the standard LST EN 197-1:2000, manufactured by the Joint Stock Company Akmenès Cementas, Naujoji Akmene, Lithuania. The setting time of Portland cement is determined by the standard LST EN 196-3:2005+ A1:2009: $t_{n}-140 \mathrm{~min}, t_{k}-190 \mathrm{~min}$. The chemical composition (in \%) is determined by the standard LST EN 196-2:2005: $\mathrm{SiO}_{2}-20.76 ; \mathrm{Al}_{2} \mathrm{O}_{3}-6.12 ; \mathrm{Fe}_{2} \mathrm{O}_{3}-$ 3.37; $\mathrm{CaO}-63.50, \mathrm{MgO}-4.01 ;\left(\mathrm{K}_{2} \mathrm{O}+\mathrm{Na}_{2} \mathrm{O}\right)-1.03$; $\mathrm{SO}_{3}-0.80$; burning loss -0.23 , insoluble residue -0.07 . The mineral composition of Portland cement (\%), calculated by the method (Bogue 1955), was the following: $\mathrm{C}_{3} \mathrm{~S}-58.54 ; \mathrm{C}_{2} \mathrm{~S}-15.29 ; \mathrm{C}_{3} \mathrm{~A}-10.40 ; \mathrm{C}_{4} \mathrm{AF}-10.17$. The specific surface of Portland cement, determined by Blein device according to the standard LST EN 1966:2010 was $420 \mathrm{~m}^{2} / \mathrm{kg}$.
EPS inclusions were received by crushing EPS packing tare waste at the Joint Stock Company Virginijus and Co., Plunge, Lithuania. The bulk density of EPS inclusions $\left(13-17 \mathrm{~kg} / \mathrm{m}^{3}\right)$ was determined according to the standard LST EN 1097-6+AC:2003/A1:2005. The particle size distribution (presented in Table 1) was determined according to the standard LST ISO 33101:2003/AC1:2005, using the set of sieves conforming to the standard LST EN 933-1:2002.

As a foamer, the air entraining additive (AEA) Ufapore TCO, Unger Fabrikker AS, Fredrikstad, Norway, was used in amount of $0.03 \%$ of Portland cement mass.

The compositions of formative mixtures of lightweight composite, subject to its density, are presented in Table 2.

The components of formative mixture were mixed by a vertical mixer MXP 1602 E, Protool, Česká Lípa, Czech Republic at a speed of $125 \mathrm{rpm}$ observing the following procedure and the duration of mixing. Water and AEA were mixed for 1 minute, then Portland cement was added and the mixing was continued for additional $2 \mathrm{~min}$, afterwards, EPS inclusions in required amount were added to porous cement mixture and mixed further for $5 \mathrm{~min}$ to uniform mass.

The prepared formative mixture was poured into moulds of required dimensions. To fill the moulds evenly, the formative mixture was slightly compacted by a metal rod of $20 \mathrm{~mm}$ diameter.

The obtained specimens of lightweight composite were demoulded after 24 hours since moulding, and then - covered with polyethylene film and kept for 28 days at a temperature of $20^{\circ} \mathrm{C}$. Finally, they were dried in the laboratory drying oven at a temperature of $50{ }^{\circ} \mathrm{C}$ to a constant mass.

\subsection{Testing methods}

The density in a dry condition of lightweight composite was determined on specimens of cube shape $(100 \times 100 \times 100) \mathrm{mm}$ by the standard LST EN $1602+$ AC: 1998.

For determination of compressibility and point load of lightweight composite, the electromechanical testing machine H10KS, Hounsfield Test Equipment LTD, Redhill, England, was used with the computer program

Table 1. Particle size distribution of EPS inclusions

\begin{tabular}{l|c|c|c|c|c|c}
\hline Value of mesh cell (mm) & 20.00 & 10.00 & 5.00 & 2.50 & 1.25 & $<1.25$ \\
\hline Fractional residue (\%) & 0.37 & 20.02 & 29.79 & 22.99 & 25.48 & 1.35 \\
\hline Full residue (\%) & 0.37 & 20.39 & 50.18 & 73.17 & 98.65 & 100 \\
\hline Aperture (\%) & 99.63 & 79.61 & 49.82 & 26.83 & 97.30 & 0.00 \\
\hline
\end{tabular}

Table 2. Compositions of formative mixtures of lightweight composite with different densities

\begin{tabular}{c|c|c|c}
\hline Density of composite, $\mathrm{kg} / \mathrm{m}^{3}$ & Size of EPS crumbs $(\mathrm{mm})$ & $\begin{array}{c}\text { Portland cement and EPS } \\
\text { crumbs ratio (mass \%) }\end{array}$ & $\begin{array}{c}\text { Water and Portland cement } \\
\text { ratio }\end{array}$ \\
\hline 150 & Not more than 5.00 & $83: 17$ & 0.80 \\
\hline 250 & Less than 20.0 & $91: 9$ & 0.65 \\
\hline 350 & Less than 20.0 & $94: 6$ & 0.50 \\
\hline
\end{tabular}


Qmat Professional. The compressibility was determined according to requirements of the standard LST EN 12431:2000/A1:2007, upon exposure to testing of 10 specimens sized $(200 \times 200 \times 50) \mathrm{mm}$ for each series of density, the combination of static loads being presented in Fig. 1. The compressibility value of lightweight composite was measured as a difference between thicknesses $d_{L}$ and $d_{B}$ (Fig. 1).

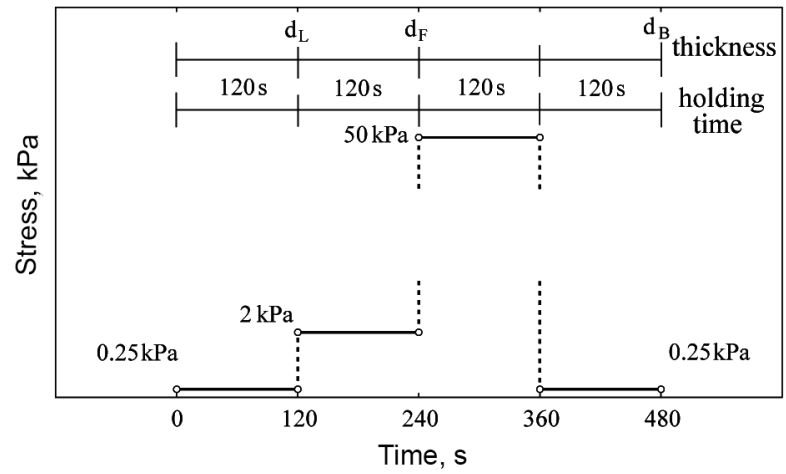

Fig. 1. Scheme of variation of thickness of lightweight composite depending on time and load

The static point load was determined on 10 specimens sized $(300 \times 300 \times 50) \mathrm{mm}$ according to the standard LST EN 12430:2000/A1:2007, by fixing value of static compressive force at the critical point in the forcedeformation curve of lightweight composite (Fig. 2). The indentor was set to move at a constant speed of $50 \mathrm{~mm} / \mathrm{min}$. The deviation of force measurement was $1-11 \mathrm{~N}$. The precision of deformation in specimens of lightweight composite (according to motion of traverse) was $0.01 \mathrm{~mm}$. The testing ran at ambient temperature of $23 \pm 2{ }^{\circ} \mathrm{C}$ and relative air humidity of $50 \pm 5 \%$.

The dynamic stiffness was determined according to the standard LST EN 29052-1:2002 by measuring of resonance frequency with the system DYPS3, Ing. Wolfgang Fellner $\mathrm{GmbH}$, Vienna, Austria. 10 specimens sized $(200 \times 200 \times 50) \mathrm{mm}$ were tested for each density of lightweight composite.

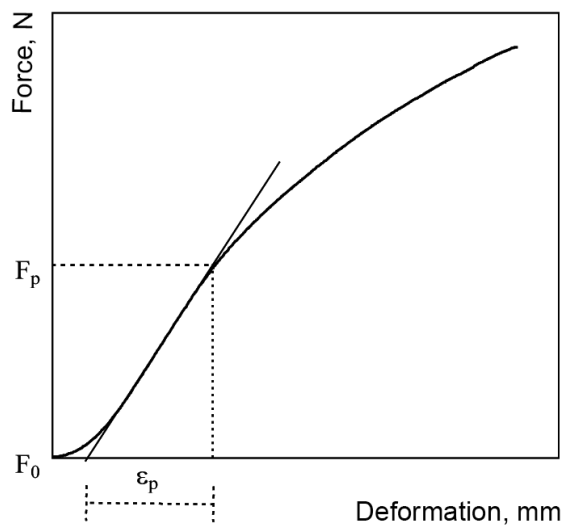

Fig. 2. Example of force-deformation curve of lightweight composite: $F_{p}$ - compressive force at critical point; $F_{0}$ - force corresponding to the preload; $\varepsilon_{p}$-deformation at $F_{p}$
The reduction in normalised impact sound pressure level was determined according to the methodology (Pavoni Belli et al. 2003) by simplified formula:

$$
\Delta L_{w}=18+15 \cdot \log \frac{m}{s},
$$

where: $\Delta L_{w}$ - decrease in normalised impact sound pressure level in $\mathrm{dB} ; m=110 \mathrm{~kg} / \mathrm{m}^{2}$ is a load of floating floor; $s$-dynamic stiffness in $\mathrm{N} / \mathrm{m}^{3}$.

The statistical processing and interrelation between two variables of experimental data was performed according to the program Satistica by least squares method (Sakalauskas 1998; Lakin 1990). The best approximating relationship was selected from some relationships via comparison of mixed correlation coefficient $R_{y . x}^{2}$ (squared correlation relationship $R_{y, x}$ ). The mean square deviation $S_{r}$ was admitted as a result scattering measure.

The surface morphology of lightweight composite was determined by stereomicroscope K-400L, Motic Group Co. LTD, Xiamen, China, with magnification up to $100 \times$ equipped with digital imagining system PVC 100C, Pixera Corporation, Los Gatos, USA.

\section{Results and discussion}

\subsection{Compressibility}

The results of investigations showed that the compressibility of lightweight composite decreases along with an increase in its density. Thus, for the lightweight composite of $150 \mathrm{~kg} / \mathrm{m}^{3}$ density, the compressibility under impact of given standard loads made $2.41-2.62 \mathrm{~mm}$; for $250 \mathrm{~kg} / \mathrm{m}^{3}$ density, it was $1.53-1.69 \mathrm{~mm}$ and for $350 \mathrm{~kg} / \mathrm{m}^{3}$ density $-0.63-0.81 \mathrm{~mm}$, i.e., the compressibility of lightweight composite can be characterised by amount and porosity degree of the matrix. Thicker walls composed of porous matrix can hinder the impact of force loads and thereby they help protecting EPS inclusions from possible deformations. The relationship between compressibility $c$ and density of lightweight composite $\rho_{a}$ can be expressed by the following equation of regression (Fig. 3):

$$
c=3.86-0.00902 \cdot \rho_{a},
$$

with the mean square deviation $S_{r}=0.055 \mathrm{~mm}(n=30)$ and coefficient of determination $R_{c \cdot \rho_{a}}^{2}=0.994$, showing that the variation of compressibility of lightweight composite is by $99.4 \%$ preconditioned by change in its density.

The data presented in Fig. 3 show that at density of lightweight composite as high as $250 \mathrm{~kg} / \mathrm{m}^{3}$, the mean value of compressibility $(1.63 \mathrm{~mm})$ is lower by $34.3 \%$ than the analogical parameter at $150 \mathrm{~kg} / \mathrm{m}^{3}$ density $(2.48 \mathrm{~mm})$. At $350 \mathrm{~kg} / \mathrm{m}^{3}$ density of lightweight composite, this value decreases by $54.4 \%$ (down to $0.71 \mathrm{~mm}$ ) versus $250 \mathrm{~kg} / \mathrm{m}^{3}$ density and by $71.4 \%$ versus $150 \mathrm{~kg} / \mathrm{m}^{3}$ density. 


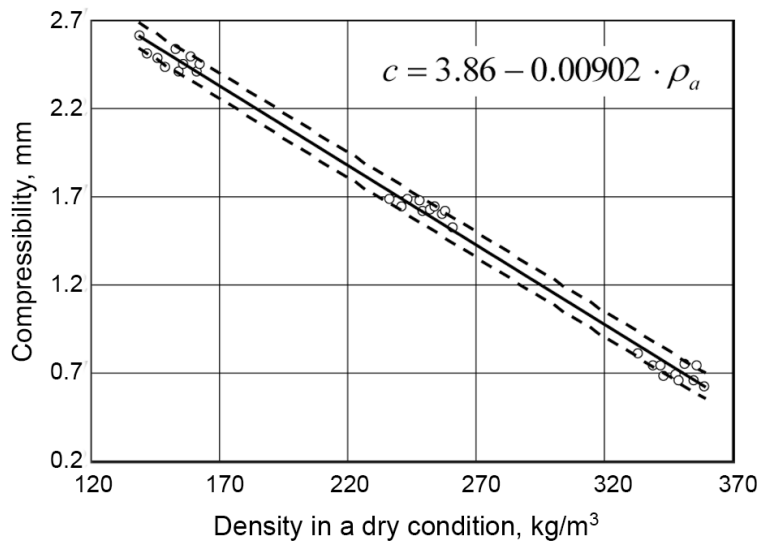

Fig. 3. The relationship between compressibility and density of lightweight composite: $\bigcirc-$ experimental data; (-) regression line; (- - -) - projected minimal and maximal values

The compressibility of less dense lightweight composite $\left(150 \mathrm{~kg} / \mathrm{m}^{3}\right)$ is also higher than that of denser one because of the fact that at larger volume of hollows in between EPS inclusions, these EPS inclusions (sized more than $5 \mathrm{~mm}$ ), under impact of static load, can freely strain themselves, owing to partial filling of these hollows by strained EPS inclusions (Fig. 4a and b). After deloading, EPS inclusions partially recover their shape and the compressibility of lightweight composite slightly decreases.

At a higher density of lightweight composite (250$350 \mathrm{~kg} / \mathrm{m}^{3}$ ), due to better filling of hollows in between EPS inclusions by porous matrix, the tending of larger EPS inclusions (less than $20 \mathrm{~mm}$ ) towards the area of these hollows under loads decreases, therefore, after deloading the compressibility changes but insignificantly (Fig. 5a and b).

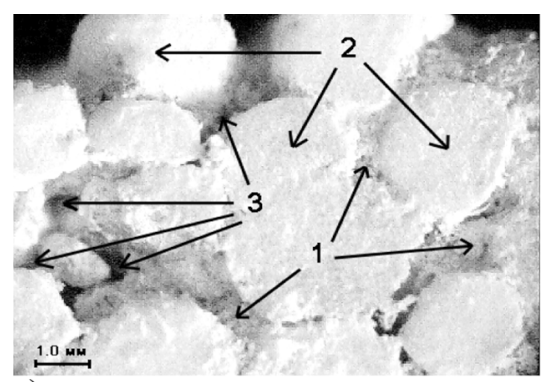

a)

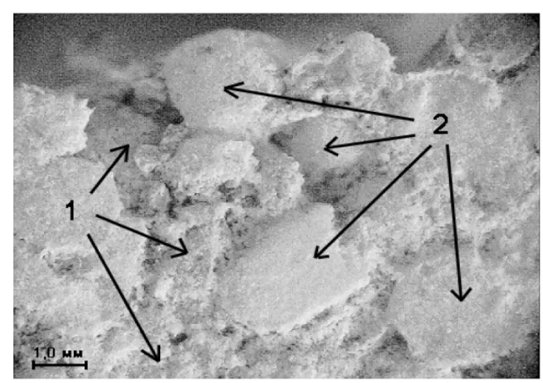

b)

Fig. 4. The surface morphology of lightweight composite of $150 \mathrm{~kg} / \mathrm{m}^{3}$ density: $\mathrm{a}$ - unstrained; $\mathrm{b}$ - strained under load. 1 - porous matrix; 2 - EPS inclusions; 3 - hollows

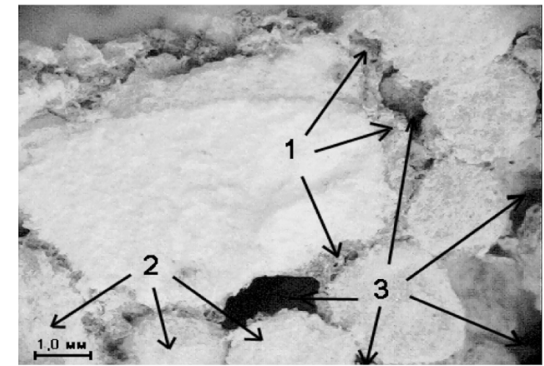

a)

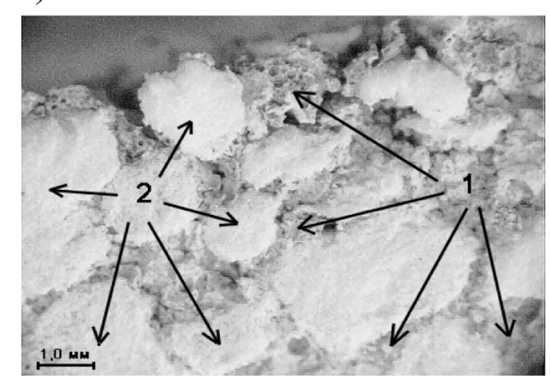

b)

Fig. 5. The surface morphology of lightweight composite of $250-350 \mathrm{~kg} / \mathrm{m}^{3}$ density: a - unstrained; $\mathrm{b}$ - strained under load. 1 - porous matrix; 2 - EPS inclusions; 3 - hollows

\subsection{Point load}

The results of investigations showed that the impact of point load $F_{p}$ on lightweight composite of different density $\rho_{a}$ is growing along with increase in its density. This relationship can be expressed by the following equation of regression (Fig. 6):

$$
F_{p}=0.0984 \cdot e^{\left(0.0098 \cdot \rho_{a}\right)},
$$

with the mean square deviation $S_{r}=0.0431 \mathrm{kN}(\mathrm{n}=30)$ and coefficient of determination $R_{F_{p}}^{2} \cdot \rho_{a}=0.998$, showing that the variation of point load of lightweight composite is by $99.8 \%$ preconditioned by change in its density.

Upon impact of point load on lightweight composite of $150 \mathrm{~kg} / \mathrm{m}^{3}$ density, the variation of compressive load reached from 0.38 to $0.49 \mathrm{kN}$, for $250 \mathrm{~kg} / \mathrm{m}^{3}$ density these fluctuations made from 1.10 to $1.31 \mathrm{kN}$, and for $350 \mathrm{~kg} / \mathrm{m}^{3}$ density - from 2.92 to $3.39 \mathrm{kN}$.

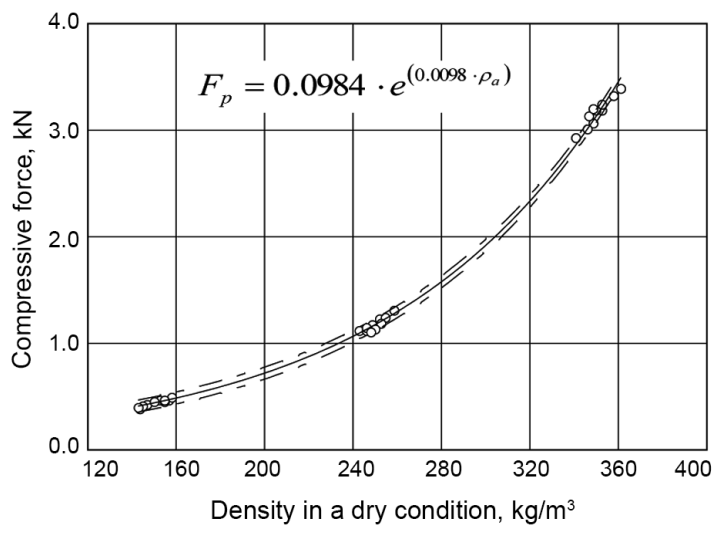

Fig. 6. The relationship between compressive force and density of lightweight composite: $\bigcirc-$ experimental data; $(-)$ - regression line; (- - - ) - projected minimal and maximal values 
The obtained results confirm that mean values of compressive force depend on structure of lightweight composite, i.e. on degree of filling of hollows in between EPS inclusions by porous matrix (Figs 4 and 5). Therefore, the mean values of point load at $250 \mathrm{~kg} / \mathrm{m}^{3}$ density of lightweight composite are higher by $62.7 \%$ than those at $150 \mathrm{~kg} / \mathrm{m}^{3}$ density; and at $350 \mathrm{~kg} / \mathrm{m}^{3}$ density, this value increases by $62.9 \%$ versus $250 \mathrm{~kg} / \mathrm{m}^{3}$ density and by $86.2 \%$ versus $150 \mathrm{~kg} / \mathrm{m}^{3}$ density.

\subsection{Dynamic stiffness}

The results of investigations showed that the dynamic stiffness $s$ ' of lightweight composite decreases along with decrease in its density $\rho_{a}$. This relationship can be expressed by the following equation of regression (Fig. 7):

$$
s^{\prime}=-29.78+0.457 \cdot \rho_{a},
$$

with the mean square deviation $S_{r}=1.653 \mathrm{MN} / \mathrm{m}^{3}$ $(\mathrm{n}=30)$ and coefficient of determination $R_{s}^{2} \cdot \rho_{a}=0.998$, showing that the variation of dynamic stiffness is by $99.8 \%$ preconditioned by change in density.

In lightweight composite of $150 \mathrm{~kg} / \mathrm{m}^{3}$ density, the dynamic stiffness made $38 \mathrm{MN} / \mathrm{m}^{3}$; in $250 \mathrm{~kg} / \mathrm{m}^{3}$ density $-96 \mathrm{MN} / \mathrm{m}^{3}$; and in $350 \mathrm{~kg} / \mathrm{m}^{3}$ density $-131 \mathrm{MN} / \mathrm{m}^{3}$.

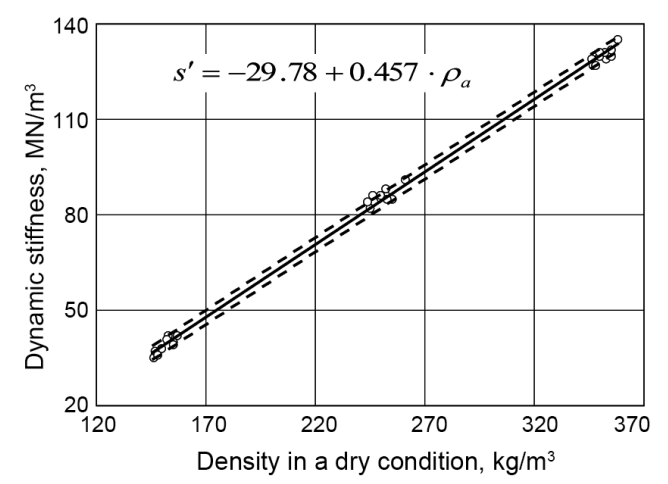

Fig. 7. The relationship between dynamic stiffness and density of lightweight composite: $\bigcirc-$ experimental data; (- regression line; (- - - -) - projected minimal and maximal values

The analysis of obtained data showed that at average of $250 \mathrm{~kg} / \mathrm{m}^{3}$ density, the dynamic stiffness of lightweight composite is higher by $60 \%$ versus $150 \mathrm{~kg} / \mathrm{m}^{3}$ density; and at average $350 \mathrm{~kg} / \mathrm{m}^{3}$ density, the dynamic stiffness by $70.3 \%$ exceeds the corresponding index of lightweight composite of $150 \mathrm{~kg} / \mathrm{m}^{3}$ density.

\subsection{Reduction in normalised impact sound pressure level}

The investigations showed that the normalised impact sound pressure level reduces along with increase in density of lightweight composite (Fig. 8). If at $150 \mathrm{~kg} / \mathrm{m}^{3}$ density the reduction in normalised impact sound pressure level was approximately $26-24 \mathrm{~dB}$, then at $250 \mathrm{~kg} / \mathrm{m}^{3}$ density it was $20-19 \mathrm{~dB}$, and at $350 \mathrm{~kg} / \mathrm{m}^{3}$ density was $17-16 \mathrm{~dB}$.
The relationship between reduction in normalised impact sound pressure level $\Delta L_{w}$ and density $\rho_{a}$ can be expressed by the following equation (Fig. 8):

$$
\Delta L_{w}=246.2 \cdot \rho_{a}^{-0.457},
$$

with the mean square deviation $S_{r}=0.159 \mathrm{~dB}(\mathrm{n}=30)$ and coefficient of determination $R_{\Delta L_{w} \cdot \rho_{a}}^{2}=0.997$, showing that the variation of reduction in normalised impact sound pressure level is by $99.7 \%$ preconditioned by change in density of lightweight composite.

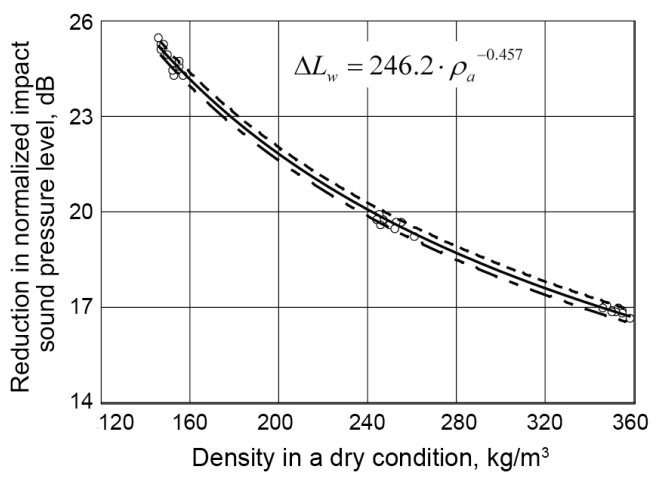

Fig. 8. The relationship between reduction in normalised impact sound pressure level and density of lightweight composite: $\bigcirc-$ experimental data; $(-)$ - regression line; $(---)$ - projected minimal and maximal values

The analysis of obtained data showed that at $250 \mathrm{~kg} / \mathrm{m}^{3}$ density of lightweight composite, the mean value of reduction in normalised impact sound pressure level $(20 \mathrm{~dB})$ is lower by $20 \%$ than that at $150 \mathrm{~kg} / \mathrm{m}^{3}$ density $(25 \mathrm{~dB})$ and that at $350 \mathrm{~kg} / \mathrm{m}^{3}$ density this value $(17 \mathrm{~dB})$ decreases by $15 \%$ versus $250 \mathrm{~kg} / \mathrm{m}^{3}$ density and by $32 \%$ versus $150 \mathrm{~kg} / \mathrm{m}^{3}$ density.

Upon comparison of the obtained results on reduction in normalised impact sound pressure level of lightweight composite with the data from references (Dikavičius, Miškinis 2009; Miškinis 2010), which present impact sound insulation specifications for modern foamy and fibrous materials, one can state that the lightweight composite under investigation is an effective impact sound insulating material and can be successfully used in multilayer enclosure constructions.

The results of performed investigations (including the determination of compressibility) showed that the lightweight composite in question can be used in constructions of floating floor with load as high as $5.0 \mathrm{kPa}$ (Buska et al. 2008; Dikavičius, Miškinis 2009; Miškinis 2010). For applications with loads exceeding $5.0 \mathrm{kPa}$, it is necessary to carry out further investigations to determine creep of lightweight composite, i.e. change in thickness under impact of corresponding dynamic loads.

\section{Conclusions}

The performed investigations on performance of the lightweight composite enable extending the field of its application to construction of floor and roofs. 
It is established that at change in density of lightweight composite within indicated limits, its compressibility value was $2.62-0.63 \mathrm{~mm}$; point load $-0.26-$ $3.42 \mathrm{kN}$; dynamic stiffness $-35-135 \mathrm{MN} / \mathrm{m}^{3}$; reduction in normalised impact sound pressure level $-26-17 \mathrm{~dB}$.

It is established that the properties of lightweight composite are mostly subject to its density, which, in its turn, is determined by the following indices:

- the amount of partitions between pores in the porous cement matrix and the thickness of their walls;

- the volume of hollows, which appear in between EPS inclusions, as well as the porosity of the porous cement matrix;

- the amount of EPS inclusions per volume unit of lightweight composite;

- the particle size distribution of EPS inclusions;

- the production technology of lightweight composite (water and Portland cement ratio, the amount of AEA and etc.).

\section{Acknowledgement}

This work was supported by Research Council of Lithuania (contract No ATE-07/2012).

\section{References}

Ahmed, A.; Ugai, K.; Kamei, T. 2011. Investigation of recycled gypsum in conjunction with waste plastic trays for ground improvement, Construction and Building Materials 25(1): 208-217.

http://dx.doi.org/10.1016/j.conbuildmat.2010.06.036

Bhutta, M. A. R.; Ohama, Y.; Tsuruta, K. 2011. Strength properties of polymer mortar panels using methyl methacrylate solution of waste expanded polystyrene as binder, Construction and Building Materials 25(2): 779-784. http://dx.doi.org/10.1016/j.conbuildmat.2010.07.006

Binici, H.; Gemci, R.; Kaplan, H. 2012. Physical and mechanical properties of mortars without cement, Construction and Building Materials 28(1): 357-361.

http://dx.doi.org/10.1016/j.conbuildmat.2011.08.056

Bogue, R. H. 1955. The Chemistry of Portland Cement. $2^{\text {nd }}$ Ed. New York: Reinhold Publishing Corp. 793 p.

Bouvard, D.; Chaix, J. M.; Dendievel, R.; Fazekas, A.; Létang, J. M.; Peix, G.; Quenard, D. 2007. Characterization and simulation of microstructure and properties of EPS lightweight concrete, Cement and Concrete Research 37(12): 16661673.

http://dx.doi.org/10.1016/j.cemconres.2007.08.028

Buska, A.; Lybye, D.; Mačiulaitis, R. 2008. Effect of dynamic load on value of point load of mineral wool boards, Materials Science (Medžiagotyra) 14(3): 268-272.

Dikavičius, V.; Miškinis, K. 2009. Change of dynamic stiffness of open and closed cell resilient materials after compressibility test, Materials Science (Medžiagotyra) 15(4): 368-371.

Gaggino, R. 2006. Light and insulant plates for housing external closure, Construction and Building Materials 20(10): 917-928.

http://dx.doi.org/10.1016/j.conbuildmat.2005.06.018

GHK - Government of the Hong Kong, environmental protection department, waste reduction and ecopark group. 2010. Waste reduction and recovery factsheet no.5. [cited
01 October 2011]. Available from Internet: https://www. wastereduction.gov.hk/en/materials/info/wr_eps.pdf

Guan, H.; Liu, S.; Duan, Y. 2007. Expanded polystyrene as an admixture in cement-based composites for electromagnetic absorbing, Journal of Materials Engineering and Performance 16(1): 68-72. http://dx.doi.org/10.1007/s11665006-9010-2

Kim, K.-W.; Jeong, G.-C.; Yang, K.-S.; Sohn, J.-y. 2009. Correlation between dynamic stiffness of resilient materials and heavyweight impact sound reduction level, Building and Environment 44(8): 1589-1600.

http://dx.doi.org/10.1016/j.buildenv.2008.10.005

Kligys, M. 2009. Production Technology and Properties of Composite Material Made Out of Porous Cement Paste and Crushed Expanded Polystyrene. Summary of Doctoral Dissertation. Vilnius Gediminas Technical University. Vilnius: Technika. $24 \mathrm{p}$.

Kligys, M.; Laukaitis, A.; Sinica, M.; Sezemanas, G.; Dranseika, N. 2008. Investigations into the fire hazard of a composite made from aerated concrete and crushed expanded polystyrene waste, Mechanics of Composite Materials 44(2): 173-180.

http://dx.doi.org/10.1007/s11029-008-9010-4

Lakin, G. F. 1990. Biometriia. Moskva: Vyschaia Shkola. 352 s.

Leu, S.-Y.; Yang, T.-H.; Lo, S.-F.; Yang, T.-H. 2012. Optimized material composition to improve the physical and mechanical properties of extruded wood-plastic composites (WPCs), Construction and Building Materials 29(4): $120-127$.

http://dx.doi.org/10.1016/j.conbuildmat.2011.09.013

LST EN 12430:2000/A1:2007 Statybiniai termoizoliaciniai gaminiai. Elgsenos veikiant sutelktajai apkrovai nustatymas [Thermal insulating products for building applications - Determination of behaviour under point load]. Lietuvos standartizacijos departamentas [Lithuanian Standards Board], 2007. $3 \mathrm{p}$.

LST EN 12431:2000/A1:2007 Statybiniai termoizoliaciniai gaminiai. Slankiuju grindu izoliaciniu gaminiu storio nustatymas [Thermal insulating products for building applications - Determination of thickness for floating floor insulating products]. Lietuvos standartizacijos departamentas [Lithuanian Standards Board], 2007. 3 p.

LST EN 1602+AC:1998 Statybinès termoizoliacinès medžiagos. Tankio nustatymas [Thermal insulating products for building applications - Determination of the apparent density]. Lietuvos standartizacijos departamentas [Lithuanian Standards Board], 1998. $5 \mathrm{p}$.

LST EN 196-6:2010 Cemento bandymu metodai. 6 dalis. Smulkumo nustatymas [Methods of testing cement Part 6: Determination of fineness]. Lietuvos standartizacijos departamentas [Lithuanian Standards Board], 2011. $17 \mathrm{p}$.

LST EN 29052-1:2002 Akustika. Dinaminio standumo nustatymas. 1 dalis. Medžiagos, naudojamos gyvenamuosiuose pastatuose po judriosiomis grindimis [Acoustics - Determination of dynamic stiffness - Part 1: Materials used under floating floors in dwellings]. Lietuvos standartizacijos departamentas [Lithuanian Standards Board], 2002. 6 p.

LST EN 13501-1:2007 Statybos gaminiu ir statinio elementu klasifikavimas pagal deguma. 1 dalis. Klasifikavimas pagal atsako i ugni bandymu duomenis [Fire classification of construction products and building elements - Part 1: Classification using data from reaction to fire tests]. Lietuvos standartizacijos departamentas [Lithuanian Standards Board], 2007. $53 \mathrm{p}$. 
LST EN 196-2:2005 Cemento bandymu metodai. 2 dalis. Cemento chemine analize [Methods of testing cement - Part 2: Chemical analysis of cement]. Lietuvos standartizacijos departamentas [Lithuanian Standards Board], 2007. 47 p.

LST EN 196-3:2005+A1:2009 Cemento bandymu metodai. 3 dalis. Rišimosi trukmiu ir tūrio pastovumo nustatymas [Methods of testing cement - Part 3: Determination of setting times and soundness]. Lietuvos standartizacijos departamentas [Lithuanian Standards Board], 2009. 14 p.

LST EN 197-1:2000 Cementas. 1 dalis. Iprastiniu cementu sudetis, techniniai reikalavimai ir atitikties kriterijai [Cement - Part 1: Composition, specifications and conformity criteria for common cements]. Lietuvos standartizacijos departamentas [Lithuanian Standards Board], 2000. 26 p.

LST EN 1097-6+AC:2003/A1:2005 Užpildu mechaniniu ir fizikiniu savybiu nustatymo metodai. 6 dalis. Daleliu tankio ir imirkio nustatymas [Tests for mechanical and physical properties of aggregates - Part 6: Determination of particle density and water absorption]. Lietuvos standartizacijos departamentas [Lithuanian Standards Board], 2005. 5 p.

LST EN 933-1:2002 Bandymai užpildu geometrinèms savybèms nustatyti. 1 dalis. Granuliometrinès sudeties nustatymas. Sijojimo metodas [Tests for geometrical properties of aggregates - Part 1: Determination of particle size distribution - Sieving method]. Lietuvos standartizacijos departamentas [Lithuanian Standards Board], 2002. 16 p.

LST ISO 3310-1:2003/AC1:2005 Laboratoriniai sietai. Techniniai reikalavimai ir bandymai. 1 dalis. Laboratoriniai pinto metalinio vielinio tinklo sietai (tpt ISO 33101:2000/Cor.1:2004) [Test sieves. Technical requirements and testing. Part 1: Test sieves of metal wire cloth (idt ISO 3310-1:2000/Cor.1:2004)]. Lietuvos standartizacijos departamentas [Lithuanian Standards Board], 2005. 2 p.

Madandoust, R.; Ranjbar, M. M.; Mousavi, S. Y. 2011. An investigation on the fresh properties of self-compacted lightweight concrete containing expanded polystyrene, Construction and Building Materials 25(9): 3721-3731.

Miškinis, K. 2010. Investigation of Resilient Materials and Their Influence on Impact Sound Insulation of Floor Constructions: Summary of Doctoral Dissertation. Kaunas University of Technology. Kaunas: Technologija. 30 p.

Mohandesi, J. A.; Refahi, A.; Meresht, E. S.; Berenji, S. 2011. Effect of temperature and particle weight fraction on me- chanical and micromechanical properties of sandpolyethylene terephthalate composites: A laboratory and discrete element method study, Composites Part B: Engineering 42(6): 1461-1467.

http://dx.doi.org/10.1016/j.compositesb.2011.04.048

Pavoni Belli, A.; Russo, F.; Schiavi, A. 2003. Measurements of dynamic stiffness to estimate the reduction in impact sound pressure level, in Proc. of the $5^{\text {th }}$ European Conference on Noise Control "Euronoise 2003", 19-21 May, 2003, Naples, Italy [CD ROM].

Poletto, M.; Dettenborn, J.; Zeni, M.; Zattera, A. J. 2011. Characterization of composites based on expanded polystyrene wastes and wood flour, Waste Management 31(4): $779-784$

http://dx.doi.org/10.1016/j.wasman.2010.10.027

Sakalauskas, V. 1998. Statistika su statistika [Statistics with statistics]. Vilnius: Margi Raštai. 228 p.

Schmidt, P. N. S.; Cioffi, M. O. H.; Voorwald, H. J. C.; Silveira, J. L. 2011. Flexural test on recycled polystyrene, Procedia Engineering 10: 930-935. http://dx.doi.org/10.1016/j.proeng.2011.04.153

Shin, C. 2006. Filtration application from recycled expanded polystyrene, Journal of Colloid and Interface Science 302(1): 267-271.

http://dx.doi.org/10.1016/j.jcis.2006.05.058

Siddique, R.; Khatib, J.; Kaur, I. 2008. Use of recycled plastic in concrete: A review, Waste Management 28(10): 18351852. http://dx.doi.org/10.1016/j.wasman.2007.09.011

Sinica, M.; Laukaitis, A.; Sezemanas, G.; Kligys, M. 2008. Operational properties of a heat-insulation composite with expanded polystyrene crumbs, Mechanics of Composite Materials 44(4): 415-424.

http://dx.doi.org/10.1007/s11029-008-9033-x

Vasudevan, R.; Sekar, A. R. C.; Sundarakannan, B.; Velkennedy, R. 2012. A technique to dispose waste plastics in an ecofriendly way - Application in construction of flexible pavements, Construction and Building Materials 28(1): 311-320.

http://dx.doi.org/10.1016/j.conbuildmat.2011.08.031

$\mathrm{Xu}$, Y.; Xu, J. J.; Li, Y. 2012. Mechanical properties of expanded polystyrene lightweight aggregate concrete and brick, Construction and Building Materials 27(1): 32-38. http://dx.doi.org/10.1016/j.conbuildmat.2011.08.030

Modestas KLIGYS. Dr, Scientific Officer of the Scientific Institute of Thermal Insulation, Vilnius Gediminas Technical University (VGTU). Doctor of Technological Sciences (materials engineering), 2009. Publications: author and co-author of 8 scientific publications and 1 patent. Research interests: cement-based composites, waste recycling and reuse, technology and application of building materials.

Marijonas SINICA. Dr, Senior Scientific Officer of the Scientific Institute of Thermal Insulation, Vilnius Gediminas Technical University (VGTU). Doctor of Technological Sciences (materials engineering), 2001. Publications: author and co-author of 1 monograph, 63 scientific publications, 39 inventions and 5 patents. Research interests: enclosures, cellular concrete, lightweight heat and fire insulating materials.

Georgijus SEZEMANAS. Dr, Senior Scientific Officer of the Scientific Institute of Thermal Insulation, Vilnius Gediminas Technical University (VGTU). Doctor of Technological Sciences (chemical engineering), 2004. Publications: author and co-author of 51 scientific publications, 12 inventions and 3 patents. Research interests: lightweight concrete and insulating materials, technology and application of materials.

Kęstutis MIŠKINIS. Dr, Engineer of the Faculty of Civil Engineering and Architecture, Kaunas University of Technology (KTU). Doctor of Technological Sciences (civil engineering), 2010. Publications: author and co-author of 4 scientific publications. Research interests: physical-mechanical properties of resilient materials.

Saulius VAITKUS. Dr, Senior Scientific Officer of the Scientific Institute of Thermal Insulation, Vilnius Gediminas Technical University (VGTU). Doctor of Technological Sciences (materials engineering), 2007. Publications: author and co-author of 20 scientific publications. Research interests: physical-mechanical and thermal-technical characteristics of thermal insulating materials and products. 